\title{
Loss and representativeness in a 43 year follow up of a national birth cohort
}

\author{
M E J Wadsworth, S L Mann, B Rodgers, D J L Kuh, W S Hilder, E J Yusuf
}

\begin{abstract}
Study objective-The aim was to describe rates of loss and assessment of representativeness during 43 years of a national birth cohort study.

Design-The study population is a class stratified random sample of all single, legitimate births that occurred during one single week in 1946; it has been studied at regular intervals, so far to 1989.

Main results-Losses through death and emigration were comparable to those in the national population of the same age. Response rates from the population resident in Britain have remained high, and the responding population is in most respects representative of the native population born in the early postwar years. Response rates within some serious physical illnesses did not differ from those of the healthy population.

Conclusions-The continuing high response rate and representativeness of this national birth cohort is likely to be the result of home based data collections and of the regular contact to provide feedback of information and to check addresses of the study population.
\end{abstract}

For many years epidemiological studies of changes over time in the health of populations used almost entirely comparisons of mortality and illness rates, and were very little concerned with changes in indicators of state of health, of risks to health, or of quality of life. Now, however, many hypotheses about the natural history and the aetiology of some prevalent conditions and about the processes of aging explore risks to health on an increasing time scale, requiring information on subjects' lives many years before the onset of illness, ${ }^{1-4}$ and even on the health and circumstances of parents and grandparents. ${ }^{3-6}$

Data on health and risks to health over a long period can be obtained from a variety of research designs. ${ }^{7}$ Longitudinal studies of individuals on whom some health data from research on this same population at an earlier period are available make use of this opportunity by catching up with the population and collecting further information on mortality or morbidity, often much later on in life. ${ }^{89}$ Other longitudinal studies may collect data prospectively, beginning usually at a stage in adult life of raised risk of a particular condition, and ask in retrospect for information about suspected risk factors encountered in earlier life. ${ }^{1011}$ Alternatively, problems of recollection and retrospective data collection may be minimised by taking a study population at birth for regular follow up. ${ }^{12-14}$

Research designs in long term studies of individuals have in common the need to find and maintain contact with their study populations, usually over many years, and to be able to estimate the risk of distortion of findings through attrition. This paper reports on population loss and the assessment of representativeness in a national longitudinal study of health and development begun at birth and continued so far until age 43 years ${ }^{12} 15$; its main concern is now with the assessment of rates of physical and cognitive aging, and their prediction from data about earlier life.

\section{Methods}

Initially the study was concerned with birth and birth circumstances in the population of all births that occurred in England, Wales and Scotland between 3rd and 9th March 1946 $(n=16695) .{ }^{121516}$ Information was collected on $13687(82 \%)$ of these births. ${ }^{15-18}$

From this study population a sample was taken for follow up. It comprised a social class stratified sample $(n=5362)$ of all the single, legitimate births that occurred in England, Wales, or Scotland in one week in March 1946. A weighting procedure compensates for the sample's stratification by father's social class by multiplying the results of those in the sampled classes (one in four of manual workers' children) by the denominator value of the sampling fraction. This study population has not been augmented in any way, and aims now to be as far as possible representative of the single, legitimate native born who are still resident in England, Wales, or Scotland; it cannot therefore be representative of immigrants.

In this paper representativeness of the original sample and of the contacted study population during childhood and adult life is assessed by comparison with census data from the population of the same or similar age. Rates of losses through death and emigration are compared with appropriate national data, and the extent of selective loss in particular subsections of the population described.

\section{Results}

THE CURRENT EXTENT OF CONTACT

The rate of contact most recently achieved at home visits to interview and measure the available population at ages $43-44$ years was $89 \cdot 7 \%$ (table I), or $85 \%$ of the population who were alive and resident in England, Wales, or Scotland, and who 
had not permanently refused to take part (table II). The greatest source of loss at 43-44 years was temporary refusal $(5.4 \%$ ) (table I), when personal or family problems made it impossible for the study member to be interviewed or measured on this occasion. By this age a higher percentage of the original population of women was interviewed $(63.9 \%)$ compared with men $(58 \cdot 1 \%)$. This difference was accounted for chiefly by the higher loss, from the total sample, of males by 43 years through death $(7.6 \%$ of males and $5.7 \%$ of females) and residence abroad $(11.9 \%$ of males and $10.6 \%$ of females), although slightly more males could not be traced $(5.9 \%$ of males compared with $3.8 \%$ of females) and were permanent refusals $(12 \cdot 4 \%$ of males and $11.6 \%$ of females).
The characteristics of the unavailable population and the representativeness of those contacted is now examined.

\section{CONTACT MAINTENANCE}

Data collection was undertaken frequently until school leaving age, and later at longer intervals, using a variety of collection methods (table II). 121718

Contact was maintained during the school years with the help of the education and school medical services. In adult life birthday cards have been sent to study members in Great Britain and to those living abroad, giving information on study findings and asking for changes of address or name to help maintain contact. When contact is lost, local health authorities (family practitioner
Table I Contact with the cohort at age 43-44 years

Table II Contacts made with the population $(n=5362)$ selected for follow up after the birth survey of 1946

\begin{tabular}{|c|c|c|c|c|c|c|c|}
\hline & Men & $\begin{array}{l}\text { As }{ }^{\circ} \\
\text { of all } \\
\text { men }\end{array}$ & Women & $\begin{array}{l}\text { As o } \\
\text { of all } \\
\text { women }\end{array}$ & $\begin{array}{l}\text { Both } \\
\text { sexes }\end{array}$ & $\begin{array}{l}\text { As }{ }^{\circ} \text { of } \\
\text { those not } \\
\text { attempted } \\
\text { or attempted }\end{array}$ & $\begin{array}{l}\text { As }{ }^{\circ}{ }_{0} \text { of } \\
\text { total cohort }\end{array}$ \\
\hline $\begin{array}{l}\text { Contact not attempted at } 43-44 \text { ye } \\
\text { for these reasons: } \\
\text { Dead } \\
\text { Living abroad } \\
\text { Permanent refusal }\end{array}$ & $\begin{array}{l}215 \\
336 \\
302\end{array}$ & $\begin{array}{r}7.6 \\
11.9 \\
10 \cdot 7\end{array}$ & $\begin{array}{l}146 \\
271 \\
238\end{array}$ & $\begin{array}{r}5 \cdot 7 \\
10 \cdot 6 \\
9 \cdot 3\end{array}$ & $\begin{array}{l}361 \\
607 \\
540\end{array}$ & $\begin{array}{l}23.9 \\
40 \cdot 3 \\
35 \cdot 8\end{array}$ & $\begin{array}{r}6 \cdot 7 \\
11 \cdot 3 \\
10 \cdot 1\end{array}$ \\
\hline Subtotal & 853 & $30 \cdot 3$ & 655 & $25 \cdot 6$ & 1508 & $100 \cdot 0$ & $28 \cdot 1$ \\
\hline $\begin{array}{l}\text { Contact attempted at } 43-44 \text { years } \\
\text { (a) Successful } \\
\text { (b) No success for these reasons: } \\
\text { Dead } \\
\text { Living abroad } \\
\text { Permanent refusal } \\
\text { Temporary refusal } \\
\text { Untraced }\end{array}$ & $\begin{array}{r}1634 \\
3 \\
6 \\
48 \\
95 \\
175\end{array}$ & $\begin{array}{l}0 \cdot 1 \\
0 \cdot 2 \\
1 \cdot 7 \\
3 \cdot 4 \\
6 \cdot 2\end{array}$ & $\begin{array}{r}1 \\
5 \\
58 \\
100 \\
101\end{array}$ & $\begin{array}{l}0 \cdot 0 \\
0 \cdot 2 \\
2 \cdot 3 \\
3 \cdot 9 \\
4 \cdot 0\end{array}$ & $\begin{array}{r}3262 \\
4 \\
11 \\
106 \\
195 \\
276\end{array}$ & $\begin{array}{l}0 \cdot 1 \\
0 \cdot 3 \\
2 \cdot 7 \\
5 \cdot 1 \\
7 \cdot 2\end{array}$ & $11 \cdot 0$ \\
\hline Subtotal & 1961 & $69 \cdot 7$ & 1893 & $74 \cdot 3$ & 3854 & $100 \cdot 0$ & $71 \cdot 9$ \\
\hline Grand total & 2814 & $100 \cdot 0$ & 2548 & $100 \cdot 0$ & 5362 & & $100 \cdot 0$ \\
\hline
\end{tabular}

\begin{tabular}{|c|c|c|c|c|c|c|c|c|c|}
\hline \multirow[b]{3}{*}{ Year } & \multirow[b]{3}{*}{$\begin{array}{l}\text { Age in } \\
\text { years }\end{array}$} & \multirow[b]{3}{*}{$\begin{array}{l}\text { Data } \\
\text { collector }\end{array}$} & \multicolumn{4}{|c|}{ Population not available } & & & \\
\hline & & & \multicolumn{2}{|c|}{ Cumulative totals } & \multicolumn{2}{|c|}{ Abroad in each year } & \multicolumn{3}{|c|}{ Population available } \\
\hline & & & Deaths & $\begin{array}{l}\text { Permanent } \\
\text { refusal }\end{array}$ & $\begin{array}{l}\text { Temporarily } \\
\text { living } \\
\text { abroad }\end{array}$ & $\begin{array}{l}\text { Total } \\
\text { emigrated } \\
\text { (between }^{\text {betacts }} \\
\text { contal }^{\text {a }}\end{array}$ & $\begin{array}{l}\text { Population } \\
\text { not } \\
\text { contacted }\end{array}$ & $\begin{array}{l}\text { Population } \\
\text { from whom } \\
\text { data } \\
\text { collected }\end{array}$ & $\begin{array}{l}\text { Per cent } \\
\text { contacted }\end{array}$ \\
\hline 1948 & 2 & $\mathrm{HV}$ & 219 & 0 & 21 & 129 & 304 & 4689 & $94^{\circ}$ \\
\hline $\begin{array}{l}1950 \\
1952\end{array}$ & $\begin{array}{l}4 \\
6\end{array}$ & $\begin{array}{l}\mathrm{HV} \\
\mathrm{SD} \\
\mathrm{SN} \text { or } \mathrm{HV}\end{array}$ & $\begin{array}{l}229 \\
232\end{array}$ & $\begin{array}{l}1 \\
1\end{array}$ & $\begin{array}{l}36 \\
39\end{array}$ & $\begin{array}{l}196(69) \\
232(39)\end{array}$ & $\begin{array}{l}200 \\
255\end{array}$ & $\begin{array}{l}4700 \\
4603\end{array}$ & $\begin{array}{l}96{ }^{\circ}{ }^{\circ} \\
95{ }^{\circ}{ }_{0}\end{array}$ \\
\hline 1953 & 7 & $\begin{array}{l}\text { SN or HV } \\
\text { SD } \\
T\end{array}$ & 232 & 1 & 42 & $249(18)$ & 358 & 4480 & $93^{\circ}$. \\
\hline 1954 & 8 & $\begin{array}{l}\text { SN or HV } \\
T\end{array}$ & 236 & 1 & 40 & $259(10)$ & 391 & 4435 & $92^{\circ}{ }_{11}$ \\
\hline 1955 & 9 & $\mathrm{SN}$ or $\mathrm{HV}$ & 239 & 1 & 40 & $275(18)$ & 626 & 4181 & $87^{\circ} "$ \\
\hline 1956 & 10 & $\mathrm{~T}$ & 240 & 1 & 37 & $273(1)$ & 734 & 4077 & $85^{\circ} \circ$ \\
\hline 1957 & 11 & $\begin{array}{l}\text { SN or HV } \\
\text { SD } \\
\text { T }\end{array}$ & 240 & 1 & 40 & $282(9)$ & 518 & 4281 & $89^{\circ} \%$ \\
\hline 1959 & 13 & $\mathrm{~T}$ & 247 & 1 & 28 & $292(13)$ & 667 & 4127 & $86^{\prime \prime} "$ \\
\hline 1961 & 15 & $\begin{array}{l}\text { SN or HV } \\
T \\
S D\end{array}$ & 250 & 1 & 26 & $295(5)$ & 516 & 4274 & $89^{\circ}$ \\
\hline 1965 & 19 & $\mathrm{HV}$ & 263 & 4 & 38 & $316(25)$ & 1180 & 3561 & $75^{\prime \prime}$ \\
\hline 1966 & 20 & $\mathbf{P}$ & 268 & 7 & 39 & 333 (18) & 816 & 3899 & $83^{\prime \prime}$ \\
\hline 1968 & 22 & $P$ & 275 & 45 & 35 & $373(43)$ & 749 & 3885 & $84^{\prime \prime}$ \\
\hline 1969 & 23 & $\mathbf{P}$ & 281 & 100 & 66 & $397(29)$ & 1492 & 3026 & $67^{\prime \prime} "$ \\
\hline 1971 & 25 & $\mathbf{P}$ & 286 & 124 & 70 & $436(48)$ & 1139 & 3307 & $74^{\prime \prime}$ \\
\hline 1972 & 26 & I & 290 & 146 & 69 & 447 (27) & 660 & 3750 & $85^{\prime \prime}$ \\
\hline 1977 & 31 & $\mathbf{P}$ & 306 & 158 & 77 & $528(96)$ & 953 & 3340 & $78^{\prime \prime}$ \\
\hline 1982 & 36 & RN & 323 & 520 & 73 & $571(65)$ & 553 & 3322 & $86^{\prime \prime}$. \\
\hline 1989 & 43 & $\mathrm{RN}$ & 365 & 540 & 607 & & $370\left(218^{b}\right)$ & 3262 & $\begin{array}{l}85 " . c \\
90^{\prime \prime \prime}, \mathrm{d}\end{array}$ \\
\hline
\end{tabular}

$\mathrm{HV}=$ health visitor; $\mathrm{SN}=$ school nurse; $\mathrm{SD}=$ school doctor; $\mathrm{T}=$ teacher; $\mathrm{P}=$ postal contact $\mathrm{I}=$ interviewer; $\mathrm{RN}=$ research nurse a Numbers in brackets indicate new emigrations between interviews bumbers in brackets comprise those not attempted. Larger number indicates those attempted, but unsucessfully, except the four deaths

cPercentage of all those available

dPercentage of all those attempted 
committees) forward letters, and interviewers visit last known addresses.

Contact rates fell during the early adult years when name and address changes were frequent, and then improved with increasing age (table II) and more consistent efforts at tracing. Losses through failure to maintain contact are also relatively low in this national sample because moving house is only a loss if study members move outside England, Wales, or Scotland.

The high contact rates of recent years may be attributable to the annual feedback of information to and from study members by way of the birthday card, and to the fact that data collection takes place in study members' homes.

\section{LOSSES THROUGH DEATH}

Deaths are notified from the NHS Central Register, and are compared with death rates in the national population of a similar age (table III). Despite the small numbers of deaths in the unweighted (observed) study population after the first year of life ( 75 deaths from 13 months to 19 years and 105 from 20-44 years) there is a similarity between weighted study death rates and those in the national population of the same age. Deaths in the oldest age range for the study are as yet likely to be underreported, particularly for the most recent years (1990-1), and will increase as further notifications are received.

There were more deaths of males $(n=216,76.8$ per 1000 in the observed population, and 86.0 per 1000 in the weighted) than females $(n=149,58.5$ per 1000 in the observed population, 63.1 per 1000 in the weighted). Deaths in the first year of life were more than twice as likely among those born into families of unskilled, agricultural, or semiskilled workers or those with unknown skills $(5 \%)$ as compared to those born into families of professional or salaried fathers $(2 \%)(p<0.05)$. Deaths before the first birthday in the clerical and skilled manual socioeconomic groups were $3 \%$ of each group.

Although death in the adult life of the study population is still rare, the risk of death in adulthood was significantly greater for those from manual social class families of origin. ${ }^{19}$

\section{LOSSES THROUGH EMIGRATION}

Despite poor national data it is clear that emigration from Great Britain was relatively high following the second world war, ${ }^{20}$ and in the national population emigrants tended to overrepresent the young and the skilled. In 1959 in the national population $58 \%$ of emigrants were aged under 30 years $(43 \%$ in the United Kingdom population) whereas $15 \%$ were over 45 years ( $37 \%$ in the United Kingdom population). In the same year $21 \%$ of men and $13 \%$ of women emigrants were in professional or managerial jobs, and only $4 \%$ of men were in labouring occupations and $6 \%$ of women were manual workers or in domestic employment. ${ }^{21} \mathrm{By}$ the mid-1960s losses through emigration of engineers and technologists were as high as $42 \%$ of the new supply (three years qualified) and $23 \%$ of scientists. ${ }^{22}$ The national data show an overall falling trend of emigration from the late 1940s to the mid-1960s, with a new peak in the mid1960 s. $^{21}$

Losses through emigration from the study population (table II) show a comparable pattern, with a rise in the immediate postwar years and a second, and smaller, peak during the study members' early adult years (22-25 years, or 1968 to 1971), which corresponded with the national "brain drain". 22 More recently, in 1977-1982, emigrations have risen again. Parents who emigrated, taking their study member child with them before the study member was 20 years old, had significantly better educational qualifications than those who continued to live in Britain $(p<0.05)$. Women study members who emigrated after 20 years also had significantly higher educational qualifications than others $(p<0.01)$, as expected. ${ }^{22}$ Study men who emigrated did not differ significantly from others in this respect.

LOSSES THROUGH REFUSAL, CHANGE OF NAME, OR CHANGE OF ADDRESS

By the end of the years of compulsory education (age 15 years) permanent refusals were negligible, but $10.8 \%$ of study members could not be contacted (table II). Members of this untraced population differed from those who were interviewed; they were more often from families

Table III Numbers of
death and death rates by
age group in the study
population, and death
rates by age group in
England, Wales and
Scotland for years
corresponding to years in
which the study
population was that age

\begin{tabular}{|c|c|c|c|c|c|}
\hline Age group & $\begin{array}{l}\text { Nos of study } \\
\text { deaths } \\
\text { (unweighted } \\
\text { total study } \\
\text { population) } \\
n=5362\end{array}$ & $\begin{array}{l}\text { Nos of study } \\
\text { deaths } \\
\text { (weighted } \\
\text { total study } \\
\text { study population) } \\
n=12472\end{array}$ & $\begin{array}{l}\text { Study death rate } \\
\text { (weighted total } \\
\text { study population) }\end{array}$ & $\begin{array}{l}\text { National death } \\
\text { rates for England } \\
\text { and Wales for years } \\
\text { corresponding to } \\
\text { study members' age }\end{array}$ & $\begin{array}{l}\text { National death } \\
\text { rates for England } \\
\text { and Scotland for } \\
\text { years corresponding } \\
\text { to study members' } \\
\text { age }\end{array}$ \\
\hline \multirow{4}{*}{$\begin{array}{l}<1 \text { month } \\
-1 \text { month and } \\
<3 \text { months } \\
-3 \text { months and } \\
<6 \text { months } \\
-6 \text { months and } \\
<1 \text { year }\end{array}$} & 123 & 309 & $24 \cdot 8$ & $24.5(1946)$ & $29.9(1946)$ \\
\hline & 25 & 61 & 4.9 & $7 \cdot 1(1946)$ & $8 \cdot 7(1946)$ \\
\hline & 19 & 55 & $4 \cdot 4$ & $6 \cdot 1(1946)$ & $8 \cdot 7(1946)$ \\
\hline & 22 & 64 & $5 \cdot 1$ & $5 \cdot 1(1946)$ & $6 \cdot 6(1946)$ \\
\hline $\begin{array}{l}\text { All deaths under } \\
1 \text { year } \\
1-4 \\
5-9 \\
10-14 \\
15-19 \\
20-24 \\
25-34 \\
35-44\end{array}$ & $\begin{array}{r}189 \\
40 \\
10 \\
11 \\
14 \\
19 \\
35 \\
47\end{array}$ & $\begin{array}{r}489 \\
94 \\
25 \\
26 \\
32 \\
52 \\
95 \\
128\end{array}$ & $\begin{array}{r}39 \cdot 2 \\
2 \cdot 0 \\
0 \cdot 4 \\
0 \cdot 4 \\
0 \cdot 5 \\
0 \cdot 9 \\
0 \cdot 8 \\
1 \cdot 1\end{array}$ & $\begin{array}{l}42.9(1946) \\
1.8(1946-50) \\
0.5(1951-55) \\
0.3(1956-60) \\
0.7(1961-65) \\
0.7(1966-70) \\
0.8(1971-75)^{\mathrm{b}} \\
1.4(1981-85)^{\mathrm{c}}\end{array}$ & $\begin{array}{l}53.8(1946) \\
2.4(1946-50) \\
0.6(1951-55) \\
0.3(1961) \\
0.7(1971) \\
0.9(1975) \\
1.9(1981)^{c}\end{array}$ \\
\hline $\begin{array}{l}\text { Total number } \\
\text { of deaths }\end{array}$ & 365 & 941 & & & \\
\hline
\end{tabular}


in which the father held a non-manual occupation $(p<0.01)$, owned their own home $(p<0.01)$, and had no problem of overcrowding $(\mathrm{p}<0.01)$, and their parents were among those with the highest educational qualifications $(p<0.001)$. They were also more inclined to have experienced a serious illness $(p<0.05) .{ }^{1924}$ These differences in social class and parental education were not accounted for by geographical or social mobility in this group of the population. There was no significant sex difference in the untraced population.

Between ages 15 and 36 years permanent refusals of contact rose, most steeply between 31 and 36 years, and then relatively little between 36 and 43 years (table II). The steep rise in refusals at 36 years may be attributable to a number of changes in study methods. There was an increased concentration on medical topics at this interview, the first introduction of measurements of blood pressure and respiratory function, and the first adult measures of height and weight.

A much longer interview had first been introduced at 26 years, which was also the only occasion when interviewers from a survey research organisation were employed. In comparison with those who refused in childhood or adolescence, those who refused in adulthood were more often men $(p<0.01)$, and from manual social class families of origin $(p<0.01)$, who in childhood had lived in overcrowded circumstances $(p<0.05)$, lacking one or more household amenity such as hot water or sole use of a bathroom $(p<0.01)$. Although they had more often than others scored in the lowest quartile of tests at ages 8 years $(p<0.01), 11$ years $(p<0.001)$, and 15 years $(p<0.01)$, and were more likely to have no educational qualifications $(p<0.001)$, they did not differ in the social class of their adult occupations.

Losses of contact with the available population in adulthood varied very little at interviews, but were considerably higher at postal contacts (table II). Compared at 36 years with the contacted population those who were available but not contacted comprised more males $(p<0.01)$ and more of those who in childhood had come from lower social class families $(p<0.05)$, who had lived in privately rented accommodation $(p<0.01)$ lacking one or more household amenity $(\mathrm{p}<0.05)$, and in overcrowded circumstances $(p<0.01)$. They had been more inclined to score in the lowest quartile of test scores at 8 years $(p<0.001), 11$ years $(p<0.01)$, and 15 years $(p<0.001)$, to have been at schools for the educationally subnormal, ${ }^{23}$ and to have relatively low or no educational qualifications $(p<0.001)$.

\section{COMPARISONS WITH CENSUS DATA}

Weighted study data were compared with census data nearest in age, or grouped age, adding English, Welsh, and Scottish information, and differences in proportions were tested using the normal approximation to the bionomial distribution.

Region of residence of each sex was compared using study data from 1950, when study members were aged four years, and national data on five year olds collected in 1951, and then using study data on 36 year olds in 1982 and census data from 1981 on the population aged 35-39 years. Greatest differences in the 1950-51 comparisons were among girls in London and the south east $(23 \%$ of cohort girls, compared with $21^{\circ}$ o in the census data), and among girls in the north east $\left(11^{\circ}\right.$ o compared with $13 \%$ in the census). In adulthood (1981-82 comparisons) percentages of residents were identical in five regions and in the other five varied by at most $2 \%$.

Social class of study fathers in 1950 was compared with 1951 census data, and in 1961 with census data from that year, and no significant differences were found. In adult life social class of men in the study did not differ significantly from census data either at 26 or at 36 years; at the older age the tendency for the sample to underrepresent manual social classes (IIIM-V) probably reflects the trendency for greater losses of contact in this section of the poulation, and the effect of immigrations on the national data. There was no comparable information on social class of women in the 1971 census. Comparison of economically active study women's social class at 36 years (in 1982 ) with that of the economically active women aged 35-44 years in the 1981 census showed no significant differences, although here too there was a slight but not significant tendency for the study to underrepresent those in manual working class occupations. Of the study women $38^{\circ}{ }_{0}$ were not economically active at 36 years compared with $45 \%$ of women in the census population. This difference may be attributable to the wide age band (35-44 years) in the available census information.

Marital status of study men and women differed significantly at 26 years from that of the national population of 25 year olds, and was also significantly different at 36 years compared with the national population of those aged $30-44$ years. At each age there was a smaller proportion of single males and females in the study population than in the census data $(p<0.001)$, and relatively more married men and women. Proportions of divorced and widowed study men and women did not differ significantly from those in the national population.

Study women who had married by age 26 years were more likely to have children than the national population of women aged 25 years in $1971(p<0 \cdot 001)$. Women study members were more likely to have two children compared with women in the national population $(p<0.001)$, who tended to have only one child by 25 years $(p<0.001)$. Similar proportions of women had three or more children at this age.

CONTACT RATES AMONG THOSE WITH PARTICULAR DISORDERS

The effect of losses on rates of contact with study members with serious illness was examined by comparison of response rates among those who had particular childhood illnesses or problems known to be a risk to adult health or social circumstances. Conditions selected were lower respiratory illness by two years [in 1117 study members $\left(25 \cdot 1{ }^{\circ}{ }_{0}\right)^{3}$ ], birth weight under $2500 \mathrm{~g}$ $\left[317\right.$ of the study population $\left(5 \cdot 9^{\circ}{ }_{0}\right)^{424}$ ], epilepsy during childhood [55 study members $\left(1 \cdot 0^{\prime \prime}{ }_{0}\right)^{25}$ ], and chronic illness lasting 3 months or more by age 15 years [ 467 or $8.7^{\circ}{ }_{0}{ }^{19}$ ]. Response rates of those known to have been admitted to mental 
hospitals by 26 years [ 149 study members $(2 \cdot 8 \%)$ ] were compared at 43-44 years with those of others.

By the time of the contact made at age 43-44 years, losses through death were high among those of low birth weight $(23.7 \%$ of this group died compared with $3.0 \%$ of the rest of the study population), in those who had had epilepsy $(23.6 \%$ had died compared with $6.6 \%$ in the rest of the population), in those who had experienced a lower respiratory illness by two years $(6.2 \%$ died compared with $3.6 \%$ in the rest of the study population), and in those who had experienced chronic illness in childhood $(13.2 \%$ had died compared with $6.1 \%$ of those free from chronic illness). The loss through death by 43-44 years of those who had been admitted to mental hospitals was slightly higher than in others $(8.7 \%$ compared with $6.8 \%$ in the rest of the population).

After omitting those who had died, response rates at age 43-44 years were not significantly lower among those who had experienced any of these problems, in comparison with those who had not; in fact response rates were higher among those who had been chronically ill in childhood $(p<0.01)$ or who had had epilepsy $(p<0.05)$. But within the group admitted to mental hospitals those known to have schizophrenia $(n=22)$ were difficult to trace. ${ }^{26}$

\section{Conclusions}

Studies of populations over long periods of time will continue to be necessary in order to study processes of aging, ${ }^{1-6}$ as durations of treatments and some illnesses increase, and since concepts of cause of illness extend over many years and into earlier generations. Methods need not be confined to long term prospective designs, ${ }^{7}$ but many methods require follow up over a number of years, and all attempt the most complete sample retention possible.

This study shows that a high rate of contact can be maintained over a long period, particularly if data collection can take place at home visits and information about the work of the study is provided to study members. While losses are inevitable in those parts of the population known to have been most difficult to reach in other population work, such as health screening, representativeness may not in many respects be impaired.
1 Barker DJP, Osmond C. Childhood respiratory infection and adult chronic bronchitis in England and Wales. $B M \mathcal{F}$ 1986; 293: 1271-5.

2 Barker DJP, Osmond C. Infant mortality, childhood nutrition and ischaemic heart disease in England and Wales. Lancet 1986; i: 1077-81.

3 Mann SL, Wadsworth MEJ, Colley JRT. Accumulation of factors influencing respiratory illness in members of a national birth cohort and their offspring. 7 Epidemiol Community Health (in press)

4 Wadsworth MEJ, Cripps HA, Midwinter RE, Colley JRT. Blood pressure in a national birth cohort at the age of 36 related to social and familial factors, smoking, and body mass. BMf 1985; 291: 1534-8.

5 Emanuel I. Maternal health during childhood and later reproductive performance. Ann NY Acad Sci 1986; 477: reprod. 39.

6 Illsley R, Mitchell RG. Low birth weight: a medical, psychological and social study. Chichester: John Wiley, psycholo 1990.

7 Wadsworth MEJ, Rodgers B. Longterm follow-up studies: a critical overview. Epidemiology Public Health 1989; 37: 533-47.

8 Lindgarde F, Furu M, Ljung BO. A longitudinal study of the significance of environmental and individual factors associated with the development of essential hypertension. $\mathcal{F}$ Epidemiol Community Health 1987; 41: 220-6.

9 Barker DJP, Bull AR, Osmond C, Simmonds SJ. Fetal and placental size and risk of hypertension in adult life. $B M \mathcal{F}$ 1990; 301: 259-62.

10 Shaper AG, Ashby D, Pocock SJ. Blood pressure and hypertension in middle-aged British men. 7 Hypertens 1988; 6: 367-74.

11 Marmot MG, Rose GA, Shipley MJ, Hamilton PJS. Employment grade and coronary heart disease in British civil servants. $₹$ Epidemiol Community Health 1978; 32: 244-9.

12 Wadsworth MEJ. The imprint of time: childhood, history and adult life. Oxford: Clarendon Press, 1991.

13 Fogelman K, ed. Growing up in Great Britain. London: Macmillan, 1983

14 Butler NR, Golding J. From birth to five. Oxford: Pergamon Press, 1986.

15 Joint Committee of the Royal College of Obstetricians and Gynaecologists and the Population Investigation Gynaecologists and the Population Investigation Committee. Maternity

16 Royal Commission on Population. Report. (Cmnd 7695.) Royal Commission on Popl

17 Wadsworth MEJ. Follow-up of the first British national birth cohort. Paediatr Perinat Epidemiol 1987; 1: 95-117.

18 Atkins E, Cherry N, Douglas JWB, Kiernan KE, Wadsworth MEJ. The 1946 British birth cohort. In: Mednick SA, Baert AE, eds. Prospective longitudinal research. Oxford: Oxford University Press, 1981: 25-30.

19 Pless IB, Cripps HA, Davies JMC, Wadsworth MEJ. Chronic physical illness in childhood and psychological and social circumstances in adolescence and early adult life. Dev Med Child Neurol 1989; 31: 746-55.

20 Coleman DA. Population. In: Halsey AH, ed. British socia trends since 1900. London: Macmillan, 1988: 36-134.

21 Oversea Migration Board. Statistics for 1963. (Cmnd 2555.) London: HMSO, 1964.

22 Committee on Manpower Resources for Science and Technology. The brain drain: report of the Working Group on Migration. (Cmnd 3417.) London: HMSO, 1967.

23 Rodgers B. The prospects for ESN(M) school leavers. Special Education: Forward Trends 1979; 6: 8-9.

24 Barker DJP, Osmond C, Golding J, Kuh D, Wadsworth MEJ. Growth in utero, blood pressure in childhood and adult life, and mortality from cardiovascular disease. $B M \mathcal{F}$ 1989; 298: $564-7$.

25 Britten N, Morgan K, Fenwick PBC, Britten H. Epilepsy and handicap from birth to age thirty six. Dev Med Child and handicap from birth

26 Rodgers B. Behaviour and personality in childhood as predictors of adult psychiatric disorder. $\mathcal{f}$ Child Psychol Psychiatry 1990; 31: 393-414. 